\title{
Keragaman Kasus Forensik Klinik di RS Bhayangkara Tingkat III Manado dari Sudut Pandang SKDI 2012 Periode Juli 2015-Juni 2016
}

\author{
${ }^{1}$ Magdalya A Lumente \\ ${ }^{2}$ Erwin G Kristanto \\ ${ }^{2}$ James F Siwu
}

\author{
${ }^{1}$ Kandidat Skripsi Fakultas Kedokteran Universitas Sam Ratulangi Manado \\ ${ }^{2}$ Bagian Ilmu Kedokteran Forensik Fakultas Kedokteran Universitas Sam Ratulangi \\ Email: Lhiaasri@gmail.com
}

\begin{abstract}
Forensic clinic is a part of medical forensics which includes examination of living victim. The knowledge and skill of a doctor are needed in case of assisting the investigators and public prosecutors in proving of a criminal act. General practitioners are required to mastering all competence levels based on the National Standard Competency of Indonesian Medical Doctors 2012 (SKDI 2012). This study was aimed to obtain all kinds of forensics clinic cases at Bhayangkara Level III Hospital Manado from July 2015 to June 2016. This was a descriprive retrospective study using data obtained from the police inquest papers, visum et repertum, and medical records. The results showed that there were $38 \%$ of cases, that fulfilled the Standard Competence of General Practitioner. Conclusion: In this study, the majority of cases were blunt violent cases. It is suggested that Bhayangkara Level III Hospital Manado become a partnership of hospital education for future doctors.
\end{abstract}

Keywords: forensic clinic, doctor competence, SKDI 2012

\begin{abstract}
Abstrak: Forensik klinik adalah bagian dari ilmu kedokteran forensik yang mencakup pemeriksaan pada korban hidup. Ilmu pengetahuan dan keterampilan seorang dokter dibutuhkan dalam membantu tugas penyidik dan penuntut umum dalam pembuktian tindak pidana. Dokter umum diwajibkan menguasai semua tingkat kompetensi yang ada di dalam buku Standar Kompetesi Dokter Indonesia 2012. Penelitian ini merujuk pada RS Bhayangkara Tingkat III Manado dengan tujuan untuk mengetahui keragaman kasus Forensik Klinik di RS Bhayangkara Tingkat III Manado periode Juli 2015-Juni 2016. Jenis penelitian ialah deskriptif retrospektif. Sumber data penelitian didapatkan dari surat permintaan visum, visum et repertum, dan rekam medis. Hasil penelitian mendapatkan 38\% kasus yang mencukupi standar kompetensi dokter umum. Simpulan: Majoritas kasus dalam studi ini ialah kekerasan tumpul. Disarankan RS Bhayangkara Tingkat III Manado dipertimbangkan sebagai kepaniteraan rumah sakit pendidikan bagi dokter muda.
\end{abstract}

Kata kunci: forensik klinik, kompetensi dokter, SKDI 2012

Forensik klinik adalah bagian dari ilmu kedokteran forensik yang mencakup pemeriksaan kedokteran terhadap korban yang hidup dengan kasus-kasus yang meliputi perkosaan (rape), pencabulan (molestation), kekerasan dalam rumah tangga (domestic violence), dan kekerasan pada anak (child abuse). ${ }^{1}$ Perilaku kekerasan atau tindak kekerasan merupakan ungkapan perasaan marah dan bermusuhan yang mengakibatkan hilangnya kontrol diri dimana individu bisa berperilaku menyerang atau melakukan suatu tindakan yang dapat membahayakan diri sendiri, orang lain dan lingkungan. ${ }^{2}$

Dari sebanyak 11.207 kasus di ranah KDRT/RP di Indonesia, 6.725 kasus berupa kekerasan terhadap istri (60\%), 
2.734 kasus kekerasan dalam pacaran (24\%), dan 930 kasus kekerasan terhadap anak perempuan (8\%). Pada tahun 2015 sama seperti tahun 2014, kekerasan tertinggi ialah kekerasan seksual (61\%). Jenis kekerasan seksual tertinggi ialah: perkosaan (1.657 kasus), pencabulan (1.064 kasus), pelecehan seksual (268 kasus), kekerasan seksual lain (130 kasus), dan percobaan perkosaan (6 kasus). ${ }^{3}$

Pembuktian tindak pidana yang terjadi pada kasus-kasus seperti diatas sangat tergantung sejauh mana penyidik dan penuntut umum mampu menunjukkan bukti-bukti. Oleh karena itu untuk membantu para penegak hukum mengungkap suatu masalah kekerasan diperlukan bantuan dokter. Tugas pokok seorang dokter dalam membantu pengusutan tindak pidana terhadap kesehatan dan nyawa manusia ialah dengan membuat visum et repertum dengan mengumpulkan kenyataan-kenyataan dan menghubungkannya satu sama lain secara logis untuk kemudian mengambil kesimpulan. ${ }^{4.5}$

Dokter spesialis atau dokter umum dengan pengetahuan ilmu forensiknya sangat dibutuhkan dalam menentukan kualifikasi luka yang tertuang dalam visum et repertum yang sangat diperlukan untuk mencari kejelasan, kebenaran, dan pembuktian-pembuktian materil yang selengkap-lengkapnya tentang suatu tindak pidana.

Ditinjau dari Standar Kompetensi Dokter Indonesia (SKDI) terdapat beberapa kompetensi yang harus dikuasai dokter umum tentang Ilmu Kedokteran Forensik. Sampai saat ini masih banyak dokter yang belum bisa melaksanakan visum et repertum dengan baik dan benar terutama dalam hal mengkualifikasi luka pada korban kekerasan dan kekerasan seksual. Dalam hal ini dokter sangat dibutuhkan karena dengan kemampuan dokter dalam melakukan kualifikasi luka yang sangat penting bagi pihak berwajib untuk menentukan berat ringannya hukuman terhadap tersangka. Oleh karean itu kedudukan seorang dokter atau dokter spesialis forensik sangat diperlukan dalam penanganan korban. Bantuan profesi dokter akan sangat menentukan adanya kebenaran faktual yang berhubungan dengan kejahatan. ${ }^{4}$

Tujuan penelitian ini yaitu mengkaji informasi keragaman kasus Forensik Klinik yang ada di RS Bhayangkara Tingkat III Manado periode Juli 2015-Juli 2016, dan mengetahui apakah keragaman kasus forensik klinik di RS Bhayangkara Tingkat III Manado sudah dapat memenuhi Standar Kompetensi Dokter Umum.

\section{METODE PENELITIAN}

Jenis penelitian ini ialah deskriptif retrospektif. Penelitian dilaksanakan di RS Bhayangkara Tingkat III Manado pada bulan September-November 2016. Populasi penelitian ini termasuk jenis populasi terjangkau ialah seluruh catatan medis pada kasus Forensik Klinik di RS Bhayangkara Tingkat III Manado periode Juli 2015 hingga Juli 2016. Besar sampel yang diambil ialah seluruh populasi terjangkau dari penelitian ini yang memenuhi kriteria inklusi dan ekslusi.

Variabel yang diteliti yaitu kasus forensik klinik, kekerasan pada perempuan, kekerasan pada anak. pemerkosaan, dan percabulan yang masuk di RS Bhayangkara Tingkat III Manado.

Data yang diperoleh ditabulasikan dan dipresentasikan dalam bentuk tabel, gambar dan grafik menurut variabel penelitian.

\section{HASIL PENELITIAN DAN BAHASAN}

Tabel 1 menunjukkan bahwa total jumlah kasus forensik klinik yang masuk di RS Bhayangkara Tingkat III Manado selama periode Juli 2015-Juni 2016 sebanyak 386 kasus. Tabel 2 memperlihatkan kasus terbanyak yang masuk di RS Bhayangkara Tingkat III Manado periode Juli 2015-Juni 2016 ialah pencabulan, diikuti oleh kekerasan dalam rumah tangga 153 kasus, kekerasan seksual 35 kasus, pemerkosaan 26 kasus dan kekerasan fisik pada anak 9 kasus. 
Lumente, Kristanto, Siwu: Keragaman kasus forensik klinis ..

Tabel 1. Jumlah kasus forensik klinik menurut data di RS Bhayangkara Tingkat III Manado periode Juli 2015 - Juni 2016

\begin{tabular}{lccc}
\hline \multicolumn{1}{r}{ Bulan } & Masuk (n) & Diperiksa & Menolak \\
\hline Juli & 40 & 40 & 0 \\
Agustus & 29 & 29 & 0 \\
September & 34 & 34 & 0 \\
Oktober & 37 & 37 & 0 \\
November & 24 & 24 & 0 \\
Desember & 15 & 15 & 0 \\
Januari & 37 & 37 & 0 \\
Februari & 34 & 34 & 0 \\
Maret & 36 & 36 & 0 \\
April & 38 & 38 & 0 \\
Mei & 42 & 42 & 0 \\
Juni & 20 & 20 & 0 \\
Jumlah & 386 & 386 & 0 \\
\hline
\end{tabular}

Tabel 2. Jumlah kasus forensik klinik berdasarkan jenis kasus di RS Bhayangkara Tingkat III Manado periode Juli 2015 - Juni 2016

\begin{tabular}{lc}
\hline \multicolumn{1}{c}{ Kasus } & Jumlah (n) \\
& \\
\hline Kekerasan Dalam Rumah Tangga & 153 \\
Percabulan & 163 \\
Kekerasan Seksual & 35 \\
Kekerasan Fisik Pada Anak & 9 \\
Pemerkosaan & 26 \\
Total & 386 \\
\hline
\end{tabular}

Tabel 3. Jumlah kasus forensik klinik berdasarkan jenis kelamin di RS Bhayangkara Tingkat III Manado periode Juli 2015 - Juni 2016

\begin{tabular}{lccccc}
\hline & \multicolumn{4}{c}{ Jenis kelamin } & Total \\
\cline { 2 - 4 } \multicolumn{1}{c}{ Bulan } & \multicolumn{2}{c}{ Laki-laki } & \multicolumn{2}{c}{ Perempuan } & (n) \\
\cline { 2 - 5 } Juli & Jumlah (n) & $\mathbf{( \% )}$ & Jumlah (n) & $\mathbf{( \% )}$ & 40 \\
Agustus & 0 & 0 & 40 & 100 & 28 \\
September & 1 & 3,6 & 27 & 96,4 & 34 \\
Oktember & 0 & 0 & 34 & 100 & 37 \\
November & 1 & 2,7 & 36 & 97,3 & 24 \\
Desember & 0 & 0 & 24 & 100 & 15 \\
Januari & 0 & 0 & 15 & 100 & 37 \\
Februari & 1 & 2,7 & 36 & 97,3 & 34 \\
Maret & 0 & 0 & 34 & 100 & 36 \\
April & 0 & 0 & 36 & 100 & 38 \\
Mei & 1 & 2,6 & 37 & 97,4 & 42 \\
Juni & 2 & 4,8 & 40 & 95,2 & 20 \\
Jumlah & 0 & 0 & 20 & 100 & 386 \\
\hline
\end{tabular}


Dari hasil penelitian didapatkan bahwa korban terbanyak berjenis kelamin perempuan dengan jumlah 380 korban $(98,5 \%)$ sedangkan korban berjenis kelamin laki-laki berjumlah 6 korban $(1,5 \%)$ (Tabel 3). Sebagian besar kasus forensik klinik yang masuk di RS Bhayangkara Tingkat III Manado seperti pencabulan, kekerasan dalam rumah tangga, kekerasan fisik pada anak, pemerkosaan dan kekerasan seksual, umumnya laki-laki yang melakukan kekerasan terhadap perempuan. Demikian pula dengan indikasi yang melapor ke polisi, tersangka dalam insiden lebih banyak dengan pelaku kekerasan ialah lakilaki dan sebagai korban ialah perempuan. ${ }^{6}$

Kekerasan dalam rumah tangga (KDRT) yang dilakukan oleh suami lebih banyak terjadi dibandingkan yang dilakukan istri. Pada pasangan suami istri, sebagai korban ialah perempuan (istri) dan pelakunya ialah laki-laki (suami) lebih sering dibandingkan korban laki-laki dan pelaku perempuan. Hal ini karena laki-laki sebagai pelaku kekerasan mempunyai pengaruh besar dan memegang peranan penting dalam rumah tangga sehingga yang menjadi korban ialah perempuan. ${ }^{7}$

Dalam perspektif gender, kondisi ini dikaitkan dengan adanya suatu kultur atau budaya patriarki yang sejak awal membentuk peradaban manusia, yang menganggap bahwa laki-laki superior terhadap perempuan dalam kehidupan pribadi, keluarga, masyarakat, dan kehidupan bernegara. Dalam menjelaskan patriarki sendiri, dapat digunakan definisi seperti apa yang disebutkan oleh Heidi I. Hartmann yakni : " a set of social relations between men, which have a material base, and which through hierarchical establish or create independence and solidarity among men that enable them to dominate women. ",8.

Tabel 4 menunjukan jumlah kasus terbanyak yang masuk di RS Bhayangkara Tingkat III Manado ialah kekerasan tumpul $(99,4 \%)$, dan pengguguran kandungan $(0,6 \%)$. Hal ini sejalan dengan penelitian yang dilakukan Afandi et al. ${ }^{9}$ bahwa luka lecet dan memar merupakan jenis luka yang paling sering ditemukan. Untuk kasus pengguguran walaupun mencukupi, tetapi kasus yang ditemukan hanya $0,6 \%$. Hal ini dikarenakan tidak adanya pelapor, maka polisi sukar menegakkan hukum. ${ }^{10}$ Untuk kasus kekerasan tajam, trauma kimia, luka tembak, luka listrik dan petir, trauma suhu, asfiksia, tenggelam, tidak mencukupi karena tidak ada yang masuk di RS Bhayangkara Tingkat III Manado periode Juli 2015-Juni 2016.

Untuk kepentingan penyidikan dan sebagai alat bukti maka kasus-kasus forensik klinik harus melewati prosedur medicolegal dan pembuatan visum et repertum berjumlah 386 buah. Pembuatan surat keterangan medis tidak mencukupi, karena tidak disertakan dalam lampiran visum et repertum sedangkan pembuatan sertifikat kematian tidak dievaluasi.

Pada kasus forensik klinik harus di lakukan beberapa pemeriksaan, tergantung dengan kasus. Pada kasus pemerkosaan, pencabulan dan kekerasan seksual, harus dilakukan pemeriksaan selaput dara dengan total 215 kasus. Pada beberapa kasus harus dilakukan pemeriksaan anus sebanyak 37 kasus. Pada kasus kekerasan fisik harus dilakukan pemeriksaan deskripsi luka dan derajat luka masing-masing 175 kasus dan 172 kasus. Terdapat beberapa kasus yang harus dilakukan pemeriksaan ganda karena mengalami pelecehan dan juga tindak kekerasan.

Pada Tabel 1 dan 3 yaitu tabel jumlah kasus forensik klinik menurut data di RS Bhayangkara Tingkat III Manado periode Juli 2015-Juni 2016, dapat disimpulkan bahwa jumlah kasus secara keseluruhan yang masuk di RS Bhayangkara Tingkat III Manado per bulan tergolong mencukupi.

Pada Tabel 4 dan 5 yaitu tabel kasus secara variatif berdasarkan SDKI 2012 ialah 21 item, dapat disimpulkan bahwa jumlah kasus secara variatif yang masuk di RS Bhayangkara Tingkat III Manado selama 12 bulan hanya 8 item yang mencukupi, dan 13 item yang belum mencukupi karena kasus yang masuk hanya berjumlah 1 atau 2 kasus. 
Tabel 4. Standar Kompetensi Dokter Indonesia Ilmu Kedokteran Forensik dan Medikolegal yang telah dilaksanakan sesuai kasus menurut data di RS Bhayangkara Tingkat III Manado periode Juli 2015 - Juni 2016

\begin{tabular}{ccccc}
\hline Daftar masalah & $\begin{array}{c}\text { Tingkat } \\
\text { kemampuan }\end{array}$ & $\begin{array}{c}\text { Jumlah } \\
(\mathbf{n})\end{array}$ & $\begin{array}{c}\text { Persentase } \\
(\boldsymbol{\%})\end{array}$ & $\begin{array}{c}\text { Jumlah per } \\
\text { periode KKM }\end{array}$ \\
\hline Kekerasan tumpul & $4 \mathrm{~A}$ & 177 & 99,4 & Mencukupi \\
Kekerasan tajam & $4 \mathrm{~A}$ & 0 & 0 & Tidak mencukupi \\
Trauma kimia & 3A & 0 & 0 & Tidak mencukupi \\
Luka tembak & $3 \mathrm{~A}$ & 0 & 0 & Tidak mencukupi \\
Luka listrik dan petir & 2 & 0 & 0 & Tidak mencukupi \\
Barotrauma & 2 & 0 & 0 & Tidak mencukupi \\
Trauma suhu & 2 & 0 & 0 & Tidak mencukupi \\
Asfiksia & 3A & 0 & 0 & Tidak mencukupi \\
Tenggelam & 3A & 0 & 0 & Tidak mencukupi \\
Pembunuhan anak & 3A & 0 & 0 & Tidak mencukupi \\
sendiri & & & & \\
Pengguguran & 3A & 1 & 0,6 & Mencukupi \\
Kandungan & & & & - \\
Kematian mendadak & 3B & Tidak diteliti & - & - \\
Toksikologi forensik & 3A & Tidak diteliti & - & \\
\hline
\end{tabular}

Tabel 5. Keterampilan Klinis Kedokteran Forensik dan Medikolegal yang telah dilaksanakan sesuai kasus menurut data di RS Bhayangkara Tingkat III Manado periode Juli 2015 - Juni 2016

\begin{tabular}{cccc}
\hline Medikolegal & Kompetensi & $\begin{array}{c}\text { Jumlah } \\
(\mathbf{n})\end{array}$ & $\begin{array}{c}\text { Jumlah per periode } \\
\text { KKM }\end{array}$ \\
\hline Prosedur Medikolegal & $4 \mathrm{~A}$ & 386 & Mencukupi \\
Pembuatan visum et repertum & $4 \mathrm{~A}$ & 386 & Mencukupi \\
Pembuatan surat keterangan & $4 \mathrm{~A}$ & 0 & Tidak Mencukupi \\
medis & & & - \\
Pembuatan sertifikat kematian & $4 \mathrm{~A}$ & Tidak dievaluasi & Jumlah per periode \\
\hline Forensik klinik & Kompetensi & Jumlah & Kencukupi \\
& & & Mencukupi \\
\hline Pemeriksaan selaput dara & 3 & 215 & Mencukupi \\
Pemeriksaan anus & $4 \mathrm{~A}$ & 37 & Mencukupi \\
Deskripsi luka & $4 \mathrm{~A}$ & 175 &
\end{tabular}

Tabel 6. Kesimpulan total jumlah kasus secara keseluruhan.

\begin{tabular}{cccc}
\hline \multicolumn{2}{c}{ Kasus mencukupi } & \multicolumn{2}{c}{ Kasus tidak mencukupi } \\
\hline Jumlah Bulan & Persentase & Jumlah Bulan & Persentase \\
$(\mathrm{n})$ & $(\%)$ & $(\mathrm{n})$ & $(\%)$ \\
12 & 100 & 0 & 0 \\
\hline
\end{tabular}

Tabel 7 . Kesimpulan total jumlah kasus secara variatif

\begin{tabular}{cccc}
\hline \multicolumn{2}{c}{ Kasus Mencukupi } & \multicolumn{2}{c}{ Kasus Tidak Mencukupi } \\
\hline Jumlah & Persentase & Jumlah & Persentase \\
$(\mathrm{n})$ & $(\%)$ & $(\mathrm{n})$ & $(\%)$ \\
8 & 38 & 13 & 62 \\
\hline
\end{tabular}




\section{SIMPULAN}

Dari hasil penelitian mengenai keragaman kasus Forensik Klinik di RS Bhayangkara Tingkat III Manado dari sudut pandang SKDI 2012 periode Juli 2015-Juni 2016 dapat disimpulkan bahwa:

1. Jumlah total keseluruhan kasus yang masuk di RS Bhayangkara Tingkat III Manado periode Juli 2015-Juni 2016 ialah $100 \%$ mencukupi untuk setiap periode KKM.

2. Jumlah kasus secara variatif menurut SKDI 2012 didapatkan hasil 38\% yang mencukupi, dan masih $62 \%$ yang belum mencukupi.

3. Hampir seluruh kasus yang masuk di RS Bhayangkara Tingkat III Manado ialah kasus kekerasan tumpul.

4. Kasus yang tidak mencukupi untuk kompetensi dokter umum ialah kasus trauma kimia, kekerasan tajam, luka tembak, asfiksia, tenggelam, dan pembunuhan anak sendiri.

\section{SARAN}

Dilihat dari banyaknya kasus forensik klinik yang masuk di RS Bhayangkara Tingkat III Manado dan jika dikaji dengan waktu pendidikan coass di Bagian Forensik selama 2 minggu dengan total kasus yang didapatkan rata-rata 27-28 kasus per 2 minggu, maka sangat baik jika dimanfaatkan bagi mahasiswa kedokteran (dokter muda) sebagai calon dokter.

Perlu dilakukan penelitian lebih lanjut dengan data yang lebih banyak sehingga dapat memberikan gambaran mengenai keragaman kasus forensik klinik di RS Bhayangkara Tingkat III Manado.

\section{DAFTAR PUSTAKA}

1. Stark MM. Medical Forensic Medicine A Physician's Guide (2nd ed). New Jersey: Humana Press Inc, 2005.

2. Stuart dan Sundeen. Perilaku kekerasan 1995. Available from: http://digilib.unimus.ac.id/files/diskl/12 8/jtptunimus-gdl-ipungmdg()a-6384-2babii.pdf

3. Lembar Fakta Catatan Tahunan (Catahu) 2016. Available from: http://www.komnasperempuan.go.id/w p-content/uploads/2016/03/LembarFakta-Catatan-Tahunan-_CATAHU_Komnas-Perempuan-2016.pdf

4. Idries AM, Tjiptomartono AL. Penerapan Ilmu Kedokteran Forensik dalam Proses Penyidikan (Edisi revisi). Jakarta, 2013; p. 1-143.

5. Bagian Kedokteran Forensik Fakultas Kedokteran Universitas Indonesia. Ilmu Kedokteran Forensik. Ilmu Kedokteran Forensik (1st ed). Jakarta, 1997; p. 5-16.

6. Anderson KL. Theorizing gender in intimate partner violence research. Jurnal of Sex Roles. 2005;52:853-64.

7. Chrysos ES, Taft CT, King LA, King D W. Gender, partner violence and perceived family functioning among a sampel of Vietnam veterans. Journal Violence and Victims. 2005;20:549-59.

8. Jaggar AM, Rothenberg PS. Feminist Frameworks (3rd ed). USA: Mc Graw Hill, 2005.

9. Afandi D, Rosa WY, Suyanto, Khodijah, Widyaningsih C. Karakteristik kasus kekerasan dalam rumah tangga. Artikel Penelitian. 2012:435.

10. Sampurna B, Samsu Z, Siswa TD. Peranan Ilmu Forensik dalam Penegakan Hukum (1st ed). Jakarta: Pustaka Dwipar, 2008; p. 77-98. 